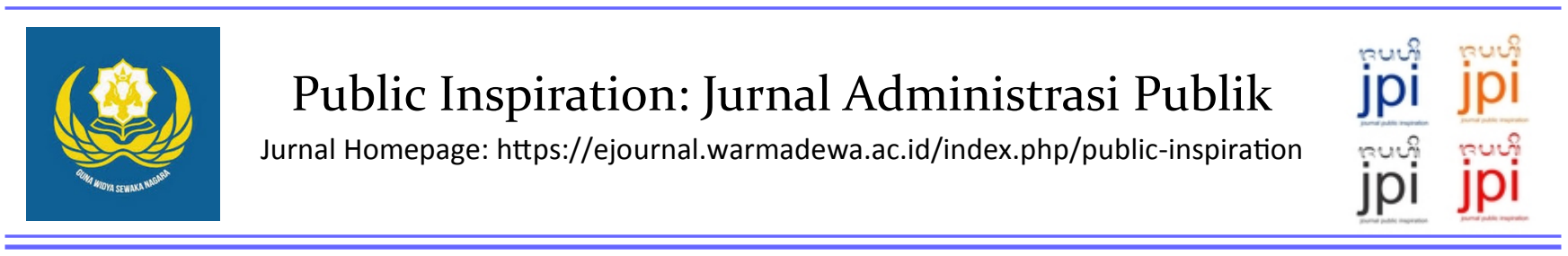

\title{
Kerjasama Pemerintah dan Swasta Dalam Pengelolaan Limbah Medis Covid-19 di Kota Madiun
}

\author{
Arimurti Kriswibowo, Amelia Wahyuningtiyas, Nur Wandira Kusmayadi dan Khusnul Prasetyo \\ Universitas Pembangunan Nasional “Veteran” Jawa Timur, Surabaya, Jawa Timur-Indonesia \\ Email Corespondence: arimurti.adne@upnjatim.ac.id
}

How to Cite: Kriswibowo, A., Wahyuningtyas, A., Kusmayadi, N, W., Prasetyo, K. (2021). Kerjasama Pemerintah dan Swasta Dalam Pengelolaan Limbah Medis Covid-19 di Kota Madiun. Public Inspiration: Jurnal Administrasi Publik, 6 (1): 8-18. DOI: https://doi.org/10.22225/pi.6.1.2021.8-18

\begin{abstract}
The increasing spread of disease caused by the SARS-CoV-2 virus in Madiun City is also in line with the increase in the amount of medical waste generated from handling COVID-19 both in Hajj Dormitories, Emergency Medical Train (EMT) and dr. Soedono Kota Madiun is categorized as B3 waste. To solve the problem of medical waste COVID-19, the Madiun City Health, Population Control, and Family Planning Agency (Dinkes-PPKB) collaborates with PT. Triata Mulia Indonesia in managing COVID-19 medical waste, considering that B3 waste management can only be carried out by the government, third parties, and hospitals that have incinerators. This study aims to describe the partnership between DinKes-PPKB Madiun City and PT. Triata Mulia Indonesia in managing COVID-19 medical waste based on the hollow state theory, as well as examining the benefits and obstacles faced in its implementation. This research uses descriptive qualitative research methods, with data collection techniques in the form of interviews, observation, and documentation. The results of this study indicate that the collaboration between the Health Office-PPKB Madiun City and PT. Triata Mulia Utama in terms of managing COVID-19 medical waste has been running effectively because both parties have carried out their respective roles.
\end{abstract}

Keyword: COVID-19 medical waste; hollow State; partnership; waste management

\begin{abstract}
Abstrak
Meningkatnya penyebaran penyakit yang disebabkan oleh virus SARS-CoV-2 di Kota Madiun seiring pula dengan peningkatan jumlah limbah medis yang dihasilkan dari penanganan COVID-19 baik di Asrama Haji, Emergency Medical Train (EMT) maupun RSUD dr. Soedono Kota Madiun dikategorikan sebagai limbah B3. Untuk mengatasi masalah limbah medis COVID-19, Dinas Kesehatan, Pengendalian Penduduk, dan Keluarga Berencana (Dinkes-PPKB) Kota Madiun bekerja sama dengan PT. Triata Mulia Indonesia dalam pengelolaan limbah medis COVID-19, mengingat pengelolaan limbah B3 hanya dapat dilakukan oleh pemerintah, pihak ketiga, dan rumah sakit yang memiliki insinerator. Penelitian ini bertujuan untuk mendeskripsikan kemitraan antara DinKes-PPKB Kota Madiun dan PT. Triata Mulia Indonesia dalam pengelolaan limbah medis COVID-19 berdasarkan teori hollow state, serta mengkaji manfaat dan kendala yang dihadapi dalam pelaksanaannya. Penelitian ini menggunakan metode penelitian deskriptif kualitatif, dengan teknik pengumpulan data berupa wawancara, observasi, dan dokumentasi. Hasil penelitian ini menunjukan bahwa kerjasama antara Dinkes-PPKB Kota Madiun dengan PT. Triata Mulia Utama dalam hal pengelolaan limbah medis COVID-19 sudah berjalan dengan efektif dikarenakan kedua belah pihak sudah menjalankan perannya masing-masing dengan baik.
\end{abstract}

Kata Kunci: Kemitraan; Hollow State; Pengelolaan Limbah; Limbah Medis COVID-19 


\section{Pendahuluan}

Berdasarkan data yang dilansir bahwa pertanggal 12 April 2021 jumlah total kasus konfirmasi positif COVID-19 di Kota Madiun secara keseluruhan mencapai 2066 kasus positif (dashboard.madiunkota.go.id, 2021). Di Kota Madiun, masyarakat yang terkonfirmasi positif COVID19 baik gejala ringan maupun tanpa gejala maka akan langsung ditujukan ke Wisma Haji dan Emergency Medical Train (EMT) atau gerbong kereta medis darurat milik PT. INKA untuk segera diisolasi sesuai dengan prosedur yang berlaku. Emergency Medical Train (EMT) atau kereta medis darurat milik PT INKA (Persero) mempunyai kapasitas 48 tempat tidur dalam satu trainset. Sedangkan Gedung Asrama Haji mempunyai kapasitas 92 tempat tidur, namun tidak semuanya terisi penuh karena aturan maksimal 60 persen dari kapasitas. Selain kedua tempat tersebut, Rumah Sakit Umum Daerah (RSUD) dr. Soedono Kota Madiun, Jawa Timur, juga merupakan rujukan bagi pasien yang terkonfirmasi positif COVID-19, namun sayangnya penuh akibat tren kenaikan angka positif COVID-19. Meningkatnya penyebaran penyakit yang disebabkan oleh virus SARS-CoV-2 seiring pula dengan peningkatan jumlah limbah medis yang dihasilkan dari penanganan COVID-19, Limbah medis ini tidak hanya dihasilkan dari aktivitas fasilitas kesehatan, namun juga dari penggunaan Alat Pelindung Diri (APD) masyarakat sehari-hari seperti masker sekali pakai dan face shield. Setelah pandemi COVID-19 di Indonesia, jumlah timbunan limbah medis termasuk masker dan APD diperkirakan berjumlah 1.662,75 ton pada periode Maret hingga September 2020 (Prasetiawan, 2020).

Limbah medis di Indonesia tergolong ke dalam limbah B3 yang pengelolaannya diatur dalam Peraturan Pemerintah Nomor 101 Tahun 2014 tentang Pengelolaan Limbah Bahan Berbahaya dan Beracun. Limbah B3 medis adalah limbah yang berpotensi terkontaminasi zat yang bersifat infeksisus yang berasal dari kegiatan pelayanan di fasilitas pelayanan kesehatan baik dari pasien maupun petugas yang meliputi sisa-sisa makanan maupun barang-barang hasil penanganan medis. Ada beberapa jenis limbah yang masuk ke dalam kategori limbah medis B3 diantaranya limbah benda tajam, limbah infeksius, limbah patologis, limbah farmasi, limbah kimia, limbah kemasan bertekanan, dan limbah logam berat. Limbah B3 medis hasil dari penanganan pasien COVID-19 tergolong limbah infeksius yaitu limbah yang terkontaminasi organisme patogen yang tidak secara rutin ada di lingkungan dan organisme tersebut dalam jumlah dan virulensi yang cukup untuk menularkan penyakit pada manusia rentan, contoh limbah yang termasuk limbah infeksisus yaitu masker dan sarung tangan bekas, alat suntik dan set infus bekas, perban dan tisu bekas, alat pelindung diri bekas, dan juga plastik/kertas bekas minuman dan makanan.

Menurut Surat Edaran Menteri Lingkungan Hidup dan Kehutanan sumber Limbah B3 COVID19 berasal dari fasilitas pelayanan kesehatan meliputi rumah sakit, pusat kesehatan masyarakat, laboratorium kesehatan, klinik pelayanan kesehatan, dan lain-lain; rumah sakit darurat COVID-19; tempat isolasi/karantina mandiri di masyarakat selain fasilitas pelayanan kesehatan meliputi hotel, wisma, apartemen, dan rumah tinggal, dan uji deteksi COVID-19; tempat vaksinasi COVID-19. Kegiatan pemeriksaan serta penanganan pasien terkonfirmasi COVID-19 di fasilitas layanan kesehatan (fasyankes) terus meningkat, begitu pula dengan limbah medis yang dihasilkan. Hal ini berpotensi menimbulkan risiko lingkungan maupun kesehatan. Limbah dengan karakteristik infeksius sangat berbahaya bagi tenaga kesehatan maupun pengunjung, dan petugas yang menangani limbah. Kementerian Lingkungan Hidup dan Kehutanan (KLHK) mencatat sejak awal pandemi COVID-19 masuk ke Indonesia pada Maret 2020 sampai awal Februari 2021 telah terdapat 6.417,95 ton timbunan limbah medis COVID-19 (Republika.co.id, 2021). Apalagi ditambah dengan adanya pelaksanaan vaksinasi masal yang saat ini sedang digencarkan oleh Pemerintah Indonesia. Pemerintah Indonesia telah memesan 329,5 juta dosis vaksin COVID-19. Dari jumlah tersebut memiliki potensi limbah yang ditimbulkan. Sampah-sampah tersebut, di antaranya berasal dari kemasan vaksin yang berdosis $2,5 \mathrm{ml}$ dengan berat 10 gr tiap botolnya, kemasan dalam bentuk spuit dengan berat sama, kemudian jarum suntik untuk penyuntikan, dengan berat 1gr (Liputan6.com, 2021). Bila tidak 
Public Inspiration: Jurnal Administrasi Publik, 6 (1) (2021), 10

Kerjasama Pemerintah dan Swasta Dalam Pengelolaan Limbah Medis Covid-19 di Kota Madiun

dikelola secara benar, limbah medis tersebut dikhawatirkan dapat menjadi masalah baru di kemudian hari. Limbah medis merupakan suatu limbah yang harus segera ditangani secara serius. Jika tidak, maka sampah itu akan menjadi salah satu mata rantai penularan COVID-19. Pemusnahan limbah infeksius COVID-19 secara tepat dan benar sangat penting, untuk memutus mata rantai penularan. Dalam UU No. 32 Tahun 2009 tentang Perlindungan dan Pengelolaan Lingkungan Hidup tegas mengatur bahwa setiap pihak yang menghasilkan limbah B3 (Bahan Berbahaya dan Beracun) wajib melakukan pengelolaan limbah B3 (Undang-Undang RI, 2009).

Pemerintah melalui Direktorat Jenderal Pengelolaan Sampah, Limbah, Bahan Beracun dan Berbahaya (PSLB3) Kementerian Lingkungan Hidup dan Kehutanan (LHK), melarang keras limbah B3 dari Fasilitas Pelayanan Kesehatan (Fasyankes) atau limbah medis dibuang di Tempat Pemroses Akhir (TPA) sampah rumah tangga atau sejenis sampah rumah tangga. Pelaksanaan pengelolaan limbah B3 medis dari kegiatan mengenai penanganan limbah infeksius atau B3 medis khusus COVID19, diatur khusus dalam Surat Edaran Menteri Lingkungan Hidup dan Kehutanan (KLHK) yang ditandatangani pada Jumat 12 Maret 2021. Surat Edaran tersebut sebagai revisi dari Surat Edaran sebelumnya yaitu Surat Edaran Nomor SE.2/MENLHK/PSLB3/PLB.3/3/2020 tentang Pengelolaan Limbah Infeksius (Limbah B3) dan Sampah Rumah Tangga dari Penanganan Corona Virus Disease (COVID-19) yang ditandatangani 24 Maret 2020. Revisi ini berdasarkan kondisi berkembangnya sumber-sumber dihasilkannya Limbah B3 dan sampah dari penanganan COVID-19 seperti hotel, wisma, rumah karantina, apartemen, dan rumah tinggal yang dijadikan tempat isolasi/karantina mandiri dimasyarakat, pelaksanaan vaksinasi COVID-19 di seluruh Indonesia yang menghasilkan jarum suntik bekas, botol ampul (vial), sisa vaksin, dan botol ampul, dan karena berkembangnya teknologi uji deteksi COVID-19 seperti GeNose C19, dan teknologi penghancur jarum suntik (Mardiyansyah, 2021). Penanganan limbah medis, termasuk limbah COVID-19 dapat diolah oleh fasilitas pelayanan kesehatan (fasyankes) atau melakukan kerja sama dengan pihak swasta. Apabila rumah sakit rujukan penanganan COVID-19 memiliki insinerator sarana pengolahan dan pemusnahan limbah medis sendiri, maka mereka dapat melakukan insenerasi di sarana tersebut. Untuk rumah sakit atau pihak yang tidak memiliki insinerator sarana pengolahan dan pemusnahan limbah medis sendiri, mereka dapat melaksanakan kerja sama dengan pihak swasta dari mulai pengangkutan hingga pengolahannya.

Limbah medis COVID-19 ditampung dan dikelola oleh masing-masing fasilitas pelayanan kesehatan (fasyankes) di Kota Madiun, untuk pengelolaan dan pemusnahan limbah medis bekerjasama dengan pihak ketiga yang berwenang melakukan pengolahan dan pemusnahan limbah B3, kecuali RSUD dr. Soedono Kota Madiun yang telah memiliki mesin insinerator sendiri sehingga dapat melaksanakan pengelolaan dan pemusnahan limbah medis COVID-19 secara mandiri. Dinas Kesehatan Pengendalian Penduduk dan Keluarga Berencana Kota Madiun (Dinkes-PPKB) sebagai penanggung jawab penanganan pasien isolasi COVID-19 di Asrama Haji Kota Madiun dan Emergency Medical Train (EMT) atau kereta medis darurat dalam mengatasi persoalan pengelolaan limbah medis COVID-19 bekerjasama dengan pihak swasta, yakni PT Triata Mulia Indonesia. PT Triata Mulia Indonesia merupakan perusahaan yang bergerak di bidang permasalahan limbah B3 atau Non-B3. Mereka melayani jasa pengangkutan limbah B3 dan Non B3, jasa pengurangan dan pengemasan limbah B3 dan Non B3, jasa pembersihan lahan/tempat/tangki terkontaminasi limbah B3, dan konsultasi di bidang pengelolaan limbah B3 dan Non B3. PT. Triata Mulia Indonesia telah mempunyai ijin yang berupa rekomendasi pengangkutan limbah B3 Kementrian Negara lingkungan hidup RI, Ijin Pengangkutan limbah B3 oleh Kementrian Perhubungan RI, dan Manifest limbah B3 dengan kode register AAH.

Pengelolaan limbah medis COVID-19 khususnya yang dihasilkan oleh fasilitas pelayanan kesehatan (fasyankes) harus dikelola dan dimusnahkan sesuai dengan persyaratan Tata Cara dan Persyaratan Teknis Pengelolaan Limbah Bahan Berbahaya Beracun (B3). Sementara itu jumlah fasilitas pengelolaan limbah Bahan Berbahaya dan Beracun (B3) yang ada di Indonesia masih 
terbatas. Dengan adanya keterbatasan kepemilikan hak untuk melakukan pengelolaan limbah medis, menjadikan kebutuhan untuk melaksanakan kerjasama dengan pihak ketiga sangat diperlukan. Guna mewujudkan pembangunan infrastruktur dan pelayanan yang tujuannya untuk mensejahterakan masyarakat memunculkan konsep hollow state yang merupakan suatu kerjasama antara pemerintah dengan swasta untuk memenuhi kebutuhan masyarakat.

Hal-hal yang menyebabkan perlunya kerjasama antara pemerintah dan swasta antara lain terbatasnya dana pemerintah, infrastruktur yang kurang memadai baik dari segi kuantitas maupun kualitas, keahlian (teknologi) yang dimiliki swasta (Utama, 2010) dikutip (Kriswibowo et al., 2020). Kemitraan pada esensinya adalah dikenal dengan istilah gotong royong atau kerjasama dari berbagai pihak, baik secara individual maupun kelompok. Dalam kemitraan terdapat upaya untuk melibatkan berbagai komponen baik sektor swasta, kelompok masyarakat, lembaga pemerintah atau nonpemerintah untuk bekerja sama mencapai tujuan bersama berdasarkan atas kesepakatan, prinsip, dan peran masing-masing. Konsep hollow state pada dasarnya menekankan urgensitas daripada kemitraan yang dipandang penting untuk meningkatkan pelayanan publik kepada masyarakat, mengurangi dampak baik sosial dan lingkungan, upaya pemenuhan kebutuhan masyarakat dan sebagai salah satu cara mempercepat program pemerintah serta meminimalisasi dampak maupun risiko yang ada. Oleh karena itu, teori hollow state dipandang relevan dan cocok dengan topik pembahasan pada penelitian ini.

Berdasarkan fenomena yang telah diuraikan sebelumnya, yang kemudian mendasari penulis melakukan penelitian untuk mengetahui dan mendeskripsikan pelaksanaan kemitraan antara Dinas Kesehatan Pengendalian Penduduk dan Keluarga Berencana Kota Madiun (Dinkes-PPKB) dengan PT Triata Mulia Indonesia dalam mengatasi persoalan pengelolalan limbah medis COVID-19 berdasarkan teori hollow state serta peran keduanya dalam pelaksanaan kerjasama ini.

\section{Konsep Teoritis}

\section{Kebijakan Publik}

Pengertian kebijakan publik oleh para pakar didefinisikan secara beragam, hal tersebut dipengaruhi oleh berbagai kepentingan yang melandasi perumusannya. Kebijakan publik pada umumnya dipahami sebagai salah satu upaya atau tindakan pemerintah yang dibuat dalam rangka melaksanakan tugas-tugas pemerintahannya, dalam wujud pengaturan atau keputusan (Anggara, 2014). Sedangkan menurut Woll dikutip (Munawir et al., 2019) bahwa kebijakan publik ialah sejumlah aktivitas pemerintah untuk memecahkan masalah di masyarakat, baik secara langsung maupun melalui berbagai lembaga yang mempengaruhi kehidupan masyarakat. Berdasarkan pendapat para ahli tersebut dapat disimpulkan bahwa kebijakan publik merupakan upaya atau tindakan yang dilakukan pemerintah untuk memecahkan masalah-masalah yang ada di masyarakat atau untuk kepentingan publik.

\section{Kemitraan Pemerintah dan Swasta (Hollow State)}

Provan dan Milward (1994) dikutip (Sulfiani, 2020) memperkenalkan pengelolaan pemerintahan baru dengan konsep hollow state, dimana dalam konsep ini pekerjaan pemerintah akan lebih banyak dikontrakkan (contracting out) kepada pihak ketiga sehingga aparat pemerintah hanya menangani urusan yang essential aja. Kerjasama Pemerintah dan Swasta dapat pula disebut sebagai Public Private Partnership (PPP) dimana dalam implementasinya telah diberlakukan dalam beberapa proses pembangunan seperti Hikmah, D. A., Maulana, A., \& Kriswibowo, A. (2020) dan dalam penelitian Kriswibowo, A., Pramestya, E. A., \& Prasetyo, K. (2020) yang meneliti proses PPP dalam pembangunan pariwisata. Dalam teori hollow state ada 3 hal utama yang menjadi fokus dalam hubungan kemitraan antara pemerintah dan swasta yakni mekanisme, struktur, dan intensif. Pertama, mekanisme yang yang membedakan hollow state dengan pemerintahan pada umumnya adalah 
mekanisme birokrasi, dimana dalam hollow state memiliki sedikit order/perintah dan mekanisme kontrol. Terdapat banyak potensi fleksibilitas untuk mengubah dan mengadaptasi sesuai dengan kebutuhan yang ada. Mekanisme pada pemerintahan termasuk didalamnya adalah dana, bantuan kontrak dan kesepakatan, dan tidak berdasarkan semata-mata pada otoritas dan sanksi dari pemerintah. Dimensi mekanisme dalam hollow state melihat tiga tipe mekanisme yaitu mekanisme pembiayaan, mekanisme penentuan kontrak, dan mekanisme evaluasi. Ketika pemerintah mampu menjadi inti agency dalam mengontrol mekanisme kemitraan maka proses kemitraan tersebut dilihat dari perspektif hollow state bersifat terintegrasi atau tidak terfragmentasi, dimana efektifitas kerja sama bisa dicapai dengan baik. Sebaliknya ketika mekanisme dalam proses kemitraan/kerja sama terpisah-pisah, dan tidak terlihatnya pemerintah dalam perannya sebagai inti agensi, maka mekanisme tersebut terfragmentasi.

Dimensi kedua dalam teori hollow state yang menjadi fokus adalah tipe struktur. Pembahasan struktur dalam hollow state tidak pada pemahaman konvensional mengenai struktur organisasi/kerja pada suatu kemitraan, melainkan membahas tentang peran dan tugas aktor-aktor yang terlibat pada kegiatan kerja sama. Tipe struktur dalam teori hollow state menyatakan bahwa struktur akan efektif ketika jaringan aktor-aktor terintegrasi dimana hanya ketika integrasi ini tersentralisasi melalui satu inti agensi. Struktur ini memfasilitasi terciptanya integrasi dan koordinasi dan relatif lebih efisien. Shared power akan menjadikan suatu lembaga menjadi lebih efektif. Pemerintah dan swasta bekerjasama dalam penyelenggaran pelayanan publik, akan tetapi pemerintah tetap menjaga fungsi sistem integrasi dengan bertanggung jawab dalam hal negosisasi, monitoring dan evaluasi kontrak. Hal-hal yang bersifat rule oriented bukan menjadi fokus dan tidak terlalu ditonjolkan dalam penyelenggaraan pelayanan publik.

Sedangkan dimensi ketiga dalam teori hollow state yakni insentif, berdasarkan perspektif ini merupakan hal-hal yang diberikan oleh pihak pemberi kerja (pemerintah) kepada pihak swasta dalam proses kemitraan yang dilakukan agar program kerja sama tersebut dapat berlangsung dengan efektif. Efektifitas suatu kemitraan juga sangat dipengaruhi oleh insentif yang terintegrasi. Pendanaan yang baik akan menunjukkan performa atau kinerja yang lebih baik dibandingkan sistem pendanaan yang minim ketika ada kesesuaian antara tingkat kewajaran dari pendanaan dengan desain kelembagaan atau kemitraan.

\section{Pengelolaan Limbah Medis}

Limbah medis adalah semua bahan limbah yang dihasilkan di fasilitas pelayanan kesehatan, seperti rumah sakit, klinik, kantor dokter, praktek gigi, bank darah, dan rumah sakit hewan/ klinik, serta fasilitas penelitian medis dan laboratorium (WHO, 2014) dikutip (Amrullah, 2019). Limbah medis di Indonesia tergolong ke dalam limbah B3 yang pengelolaannya diatur dalam Peraturan Pemerintah Nomor 101 Tahun 2014 tentang Pengelolaan Limbah Bahan Berbahaya dan Beracun. Ada beberapa jenis limbah yang masuk ke dalam kategori limbah medis B3 diantaranya limbah benda tajam, limbah infeksius, limbah patologis, limbah farmasi, limbah kimia, limbah kemasan bertekanan, dan limbah logam berat. Limbah B3 medis hasil dari penanganan pasien COVID-19 tergolong limbah infeksius yaitu Limbah yang terkontaminasi organisme patogen yang tidak secara rutin ada di lingkungan dan organisme tersebut dalam jumlah dan virulensi yang cukup untuk menularkan penyakit pada manusia rentan. Dalam Peraturan Pemerintah Nomor 101 Tahun 2014 tentang Pengelolaan Limbah Bahan Berbahaya dan Beracun tersebut dijelaskan bahwa teknis penanganan pengelolaan limbah B3 dilakukan dengan cara meliputi penetapan limbah B3, pengurangan limbah B3, penyimpanan limbah B3, pengumpulan limbah B3, pengangkutan limbah B3, pemanfaatan limbah B3, pengolahan limbah B3, dan pembuangan limbah B3.

Pengaturan mengenai penanganan pengelolaan limbah medis yang dihasilkan oleh pelayanan kesehatan juga telah diatur dalam Peraturan Menteri Lingkungan Hidup Dan Kehutanan Nomor P.56/ Menlhk-Setjen/2015 Tentang Tata Cara dan Persyaratan Teknis Pengelolaan Limbah Bahan 
Berbahaya Beracun dari Fasilitas Pelayanan Kesehatan. Dalam peraturan menteri tersebut dijelaskan bahwa pengolahan limbah B3 adalah proses untuk mengurangi dan/atau menghilangkan sifat bahaya dan/atau mengurangi sifat racun. Tujuan dari pengolahan limbah B3 adalah untuk menurunkan kadar kontaminan dalam limbah sehingga limbah mendekati tingkat kelayakan untuk dibuang ke lingkungan. Limbah medis terutama limbah infeksius sangat potensial dalam transmisi penyakit menular baik kontak langsung maupun tidak lamgsung sehingga menyebabkan pengolahan limbah B3 ini menjadi salah satu masalah serius yang harus diperhatikan di fasilitas kesehatan.

\section{Metode}

Pendekatan penelitian yang digunakan dalam penelitian ini adalah dengan menggunakan pendekatan kualitatif yang bertujuan untuk melukiskan secara sistematis fakta atau karakteristik populasi tertentu secara faktual dan cermat untuk memperoleh gambaran sacara umum mengenai suatu peristiwa atau fenomena. Merujuk pada latar belakang masalah, perumusan masalah, dan tujuan penelitian yang telah diuraikan sebelumnya, maka tipe penelitian yang digunakan adalah tipe penelitian deskriptif. Pengumpulan data dalam penelitian ini adalah dengan wawancara mendalam dengan informan, observasi, serta dokumentasi. Teknik penentuan informan yang digunakan dalam penelitian ini adalah dengan teknik purposive sampling pada informan kunci. Jenis data yang digunakan dalam penelitian ini adalah data primer yakni data yang peroleh langsung dari responden melalui wawancara sebagai hasil penelitian, serta data sekunder yang didapatkan dari berbagai literatur yang relevan dengan topik penelitian diantaranya dokumen elektronik maupun koleksi dokumen fisik dari lokasi penelitian yang dituju (Sugiyono, 2019).

Penelitian ini dilakukan selama kurang lebih satu bulan di Dinas kesehatan Pengendalian Penduduk dan Keluarga Berencana (Dinkes-PPKB) Kota Madiun. Dinkes-PPK Kota Madiun menjadi lokasi penelitian dikarenakan Dinas kesehatan Pengendalian Penduduk dan Keluarga Berencana (Dinkes-PPKB) Kota Madiun memiliki kontrak kemitraan atau kerjasama dengan PT. Triata Mulia Utama dalam pengelolaan limbah medis COVID-19. Teknis analisis data menggunakan interactive model dari Miles, Huberman \& Saldana (2014) yang dilakukan melalui beberapa tahap, mulai dari pengumpulan data (data collection), kondensasi data (data condensation), penyajian data (data display), hingga penarikan kesimpulan atau verifikasi (conclusion drawing or verification).

\section{Hasil dan Pembahasan}

Sesuai dengan tujuan penelitian yaitu untuk mengetahui dan mendeskripsikan pelaksanaan kemitraan antara antara Dinas Kesehatan Pengendalian Penduduk dan Keluarga Berencana (DinkesPPKB) Kota Madiun dengan PT Triata Mulia Indonesia dalam mengatasi persoalan pengelolalan limbah medis COVID-19 yang mengacu kepada teori hollow state menurut Provan dan Milward (1994). Dalam pengertian umum hollow state mengacu pada situasi bersama di mana lembaga pemerintah bergantung pada orang lain (firma, lembaga nonprofit, atau lembaga pemerintah lainnya) untuk bersama-sama memberikan layanan publik (Milward \& Provan, 2000). Konsep ini merupakan bentuk kemitraan dimana pekerjaan pemerintah akan lebih banyak dikontrakkan (contracting out) kepada pihak ketiga sehingga aparat pemerintah hanya berperan menangani urusan yang essential saja sedangkan pihak swasta berperan melaksanakan urusan teknis di lapangan. Dalam teori hollow state terdiri dari tiga fokus utama dalam hubungan kemitraan antara pemerintah dan swasta yaitu dimensi mekanisme, struktur, dan insentif, yang dijelaskan sebagai berikut:

\section{Mekanisme}

Berdasarkan teori hollow state yang dikemukakan oleh Provan dan Milward (1994), mengungkapkan bahwa mekanisme merupakan cara kerja yang dilaksanakan oleh kedua belah pihak meliputi mekanisme kontrak, mekanisme pembiayaan, dan mekanisme evaluasi. Kerjasama dalam hal pengelolaan limbah medis COVID-19 antara Dinas Kesehatan Pengendalian Penduduk dan Keluarga 
Berencana (Dinkes-PPKB) Kota Madiun dengan PT. Triata Mulia Utama ditandai dengan penandatanganan Memorandum of Understanding (MoU) Nomor 272/TMI/SK/XI/2020 pada hari Senin tanggal 2 November 2020. Jangka waktu dalam pelaksanaan kerjasama ini adalah 1 (satu) tahun terhitung sejak tanggal 2 Nopember 2020 hingga 1 Nopember 2021.

Kerjasama ini dilatarbelakangi karena kurang memadainya sarana prasarana yang memenuhi standart yang dimiliki oleh Dinas Kesehatan Pengendalian Penduduk dan Keluarga Berencana (Dinkes-PPKB) Kota Madiun untuk melakukan pengelolaan limbah medis ini, diantaranya adalah insinerator. Tujuan dari kerjasama ini adalah untuk melaksanakan pemusnahan limbah medis COVID19 yang termasuk kedalam limbah medis B3 kategori limbah infeksius yang menimbulkan dampak infeksi kepada orang lain sesuai dengan standart dan ketentuan yang ada. Dasar hukum yang menjadi acuan untuk melaksanakan kerjasama ini adalah Keputusan Menteri Kesehatan Republik Indonesia Nomor Hk.01.07/Menkes/537/2020 Tentang Pedoman Pengelolaan Limbah Medis Fasilitas Pelayanan Kesehatan Dan Limbah Dari Kegiatan Isolasi Atau Karantina Mandiri Di Masyarakat Dalam Penanganan Coronavirus Disease 2019 (COVID-19), serta Peraturan Menteri Lingkungan Hidup Dan Kehutanan Republik Indonesia Nomor : P.56/Menlhk-Setjen/2015 Tentang Tata Cara Dan Persyaratan Teknis Pengelolaan Limbah Bahan Berbahaya Dan Beracun Dari Fasilitas Pelayanan Kesehatan.

Sebelum memutuskan untuk memilih bermitra dengan PT. Triata Mulia Indonesia, terdapat empat perusahaan swasta yang bergerak dalam bidang pengelolaan limbah medis B3 yang telah memberikan penawaran kerjasama pengolahan limbah medis COVID-19 kepada Dinkes-PPKB Kota Madiun. Namun dari hasil rapat antara Dinkes-PPKB Kota Madiun dengan fasyankes yang ada di Kota Madiun memilih PT. Triata Mulia Indonesia sebagai mitra dalam kerjasama pengolahan Limbah medis COVID-19 di Kota Madiun dengan pertimbangan bahwa PT. Triata Mulia Indonesia telah memiliki track record baik dalam ketepatan waktu dan kedisiplinan pengangkutan limbah medis COVID-19 serta dengan pertimbangan biaya yang lebih rendah dibandingkan dengan perusahaan pengelola lain. Selain itu PT. Triata Mulia juga memiliki kerjasama dengan perusahan pengolah limbah B3 lain yang telah mendapatkan izin operasi. Hal inilah yang menjadi alasan Dinkes-PPKB Kota Madiun memilih bermitra dengan PT. Triata Mulia Indonesia.

Dalam hal pengelolaan limbah medis COVID-19 dengan pihak PT. Triata Mulia Indonesia sebagai transporter atau pengangkut juga melakukan kerjasama dengan pihak pengolah yang terdiri dari 7 perusahaan yaitu:

PT. Artama Sentosa Indonesia

PT. Wastec Internasional

PT. Jasa Madivest

PT. Wahana Pamunah Limbah Industri

PT. Andhika Makmur Persada

PT. Multi Hanna Kreasindo

PT. Prasada Pamunah Limbah Industri

Keseluruhan perusahaan yang bekerjasama dengan Dinas Kesehatan Pengendalian Penduduk dan Keluarga Berencana (Dinkes-PPKM) Kota Madiun tersebut merupakan perusahaan yang bergerak dalam usaha Pengangkutan dan/atau Pengolahan limbah B3 yang telah mendapatkan izin dari pemerintah. Dinas Kesehatan Pengendalian Penduduk dan Keluarga Berencana (Dinkes-PPKM) Kota Madiun memilih bekerjasama dengan PT. Triata Mulia Indonesia serta beberapa perusahaan pengolah limbah diatas dengan pertimbangan apabila salah satu perusahaan tersebut sedang penuh dalam penanganan limbah medis, maka dapat langsung dialihkan ke perusahaan lain yang saat itu sedang kosong dalam hal proses pengolahan limbah. Hal tersebut dilakukan karena apabila Dinas Kesehatan 
Pengendalian Penduduk dan Keluarga Berencana (Dinkes-PPKB) Kota Madiun hanya bekerja sama dengan satu perusahaan, ketika permintaan pengelolaan limbah di perusahaan tersebut penuh maka akan berakibat pada keterlambatan dalam pengambilan limbah medis COVID-19.

Dalam mekanisme pembiayaan, sistem pembiayaan pengelolaan limbah medis COVID-19 dilakukan setelah Dinas Kesehatan Pengendalian Penduduk dan Keluarga Berencana (Dinkes-PPKB) Kota Madiun menerima manifes Limbah Bahan Berbahaya dan Beracun yang dikirimkan oleh PT. Triata Mulia Indonesia sebagai bukti bahwa limbah medis telah sampai kepada pihak perusahaan pengolah. Adapun besaran harga dalam pengelolaan limbah ini sebesar Rp. 18.000 (delapan belas ribu rupiah) per kilogram. Pengangkutan limbah medis COVID-19 oleh PT Triata Mulia Indonesia dilaksanakan dua kali dalam seminggu yaitu pada hari senin dan jum'at. Limbah medis diangkut dari tempat isolasi pasien positif COVID-19 di Gedung asrama haji Kota Madiun dan dari tempat isolasi di Emergency Medical Train (EMT) atau kereta medis darurat milik PT. INKA (Persero) dalam jangka waktu sekali pengangkutan dapat menghasilkan sekitar 250 sampai $300 \mathrm{~kg}$ limbah medis COVID-19. Adapun limbah ini berasal dari peralatan medis yang digunakan dalam perawatan pasien COVID-19 maupun segala peralatan termasuk sisa makanan yang terkontak langsung dengan pasien positif COVID-19.

Mengenai mekanisme evaluasi, Dinas Kesehatan Pengendalian Penduduk dan Keluarga Berencana (Dinkes-PPKB) Kota Madiun melaksanakan evaluasi atas kinerja yang dilakukan oleh PT. Triata Mulia Indonesia dalam jangka waktu bulanan maupun di akhir tahun yang bertujuan untuk menilai keefektifan dari proses kerjasama yang dilakukan dan juga mengetahui kendala apa saja yang dihadapi dalam proses kerjasama ini. Terkait kendala yang dihadapi oleh Dinas Kesehatan Pengendalian Penduduk dan Keluarga Berencana (Dinkes-PPKB) Kota Madiun dalam pelaksanaan kerjasama ini adalah jangka waktu pengambilan limbah yang seharusnya baik dilakukan setiap hari namun hanya dapat diangkut dua kali dalam seminggu, hal ini menjadi kendala dikarenakan limbah medis COVID-19 yang tidak dapat langsung dilakukan pengolahan, mengingat limbah medis harus disimpan dalam freezer/cold storage yang dapat diatur suhunya dibawah $0 \mathrm{oC}$ di dalam TPS agar bisa bertahan 90 hari setelah pengemasan jika pengambilannya lebih dari dua hari. Namun Dinas Kesehatan Pengendalian Penduduk dan Keluarga Berencana (Dinkes-PPKB) Kota Madiun saat ini belum memiliki freezer/cold storage.

\section{Struktur}

Struktur dalam teori hollow state berfokus pada kemitraan yang dilaksanakan oleh pihak pemerintah dan pihak swasta. Hollow state tidak membahas mengenai struktur organisasi/kerja pada suatu kemitraan, melainkan membahas tentang peran dan tugas aktor-aktor yang terlibat pada kegiatan kerja sama. Provan dan Milward (1994), menjelaskan dalam dimensi struktur yaitu kerjasama akan berjalan efektif ketika semua pihak yang terlibat saling terintegrasi dan berkoordinasi. Pemerintah dan swasta bekerjasama dalam penyelenggaraan pelayanan publik, akan tetapi pemerintah tetap menjaga fungsi sistem integrasi dengan bertanggung jawab dalam hal negosiasi, monitoring, dan evaluasi kontrak (Sulfiani, 2020).

Peran Dinas Kesehatan Pengendalian Penduduk dan Keluarga Berencana (Dinkes-PPKB) Kota Madiun dalam penanganan kasus COVID-19 di Kota Madiun sebagai fungsi manajemen dan Fasilitas Layanan Kesehatan (Fasyankes) yang meliputi Puskesmas, Klinik Kesehatan serta Rumah Sakit sebagai Unit Pelaksana Teknis (UPT). Namun dikarenakan keterbatasan tempat penanganan COVID19 di Kota Madiun, Dinas Kesehatan Pengendalian Penduduk dan Keluarga Berencana (DinkesPPKB) Kota Madiun berperan menyediakan tempat isolasi darurat bagi pasien terkonfirmasi positif COVID-19 dengan ketentuan Orang Tanpa Gejala (OTG) serta dengan gejala ringan , dengan memanfaatkan Gedung asrama haji Kota Madiun dan Emergency Medical Train (EMT) atau Kereta Medis darurat milik PT. INKA (Persero) sebagai alternatif untuk menjadi tempat isolasi pasien COVID-19. Emergency Medical Train (EMT) atau Kereta Medis darurat milik PT. INKA (Persero) 
memiliki kapasitas 48 tempat tidur dalam satu trainset. Sedangkan Gedung Asrama Haji memiliki kapasitas 92 tempat tidur, namun tidak semuanya terisi karena aturan maksimal 60 (enam puluh) persen dari total kapasitas.

Sedangkan peran Dinas Kesehatan Pengendalian Penduduk dan Keluarga Berencana (DinkesPPKB) Kota Madiun dalam kerjasama pengelolaan limbah medis COVID-19 ini adalah melakukan pengemasan limbah medis COVID-19 sesuai dengan standart yaitu Limbah B3 medis dimasukkan ke dalam wadah/bin yang dilapisi kantong plastik warna kuning yang bersimbol "biohazard", Setelah 3/4 penuh atau paling lama $12 \mathrm{jam}$, sampah/limbah B3 dikemas dan diikat rapat dan dilakukan disinfeksi. Limbah B3 Medis yang telah diikat setiap 12 jam di dalam wadah/bin harus diangkut dan disimpan pada TPS Limbah B3 atau tempat yang khusus, Pada TPS Limbah B3 kemasan sampah/limbah B3 COVID-19 dilakukan disinfeksi dengan menyemprotkan disinfektan (sesuai dengan dosis yang telah ditetapkan) pada plastik sampah yang telah terikat, Setelah selesai digunakan, wadah/bin didisinfeksi dengan disinfektan seperti klorin 0,5\%, lysol, karbol, dan lain-lain.

Dalam penanganan pengemasan limbah medis ini pihak Dinas Kesehatan Pengendalian Penduduk dan Keluarga Berencana (Dinkes-PPKB) Kota Madiun belum memiliki staff khusus, dikarenakan keterbatasan anggaran dalam pengelolaan limbah medis COVID-19. Dinas Kesehatan Pengendalian Penduduk dan Keluarga Berencana (Dinkes-PPKB) Kota Madiun berencana mengalokasikan anggaran untuk mempekerjakan staff khusus pengemasan limbah medis COVID-19 ini dalam dana Belanja Tak Terduga (BTT) Dinkes-PPKB Kota Madiun. Namun saat ini usulan Belanja Tak Terduga (BTT) Triwulan untuk anggaran staff khusus pengemasan limbah medis COVID -19 masih dalam proses dan belum disetujui.

Sedangkan peran PT. Triata Mulia Indonesia sebagai pihak swasta disini adalah sebagai transporter atau pengangkut limbah medis COVID-19 serta menentukan perusahaan mana yang akan mengelola limbah medis dari Dinas Kesehatan Pengendalian Penduduk dan Keluarga Berencana (Dinkes-PPKB) Kota Madiun dengan pertimbangan perusahaan pengolah limbah yang saat itu sedang kosong atau dapat mengelola. Dalam melaksanakan pengangkutan limbah medis COVID-19 oleh PT. Triata Mulia Indonesia dilakukan dengan menggunakan alat transportasi khusus limbah infeksius yang telah memenuhi kualifikasi dan mendapatkan izin pengangkutan dari Direktorat Jenderal Perhubungan Darat. Petugas yang mengangkut limbah juga memiliki lisensi dan sertifikasi pelatihan dari Dinas Lingkungan Hidup. Adapun Standar Operasional Prosedur (SOP) yang harus dilaksanakan dalam pengangkutan limbah medis COVID-19 adalah petugas menggunakan Alat Pelindung Diri (APD), menggunakan alat angkut Limbah B3 yang telah mendapatkan Izin Pengelolaan Limbah B3 untuk kegiatan Pengangkutan Limbah B3 Kepala Instansi Lingkungan Hidup, menggunakan simbol Limbah B3, dilengkapi manifes Limbah B3.

Mengenai sistem koordinasi dilaksanakan oleh Dinas Kesehatan Pengendalian Penduduk dan Keluarga Berencana (Dinkes-PPKB) Kota Madiun secara lebih khusus oleh Bidang Pemberdayaan Masyarakat, Subbidang Kesehatan, Seksi Kesehatan Lingkungan dengan Pihak Manajemen PT. Triata Mulia Indonesia mengenai proses pengangkutan limbah medis COVID-19 seperti mengenai driver pengangkut limbah medis, jumlah limbah yang dihasilkan oleh Dinas Kesehatan Pengendalian Penduduk dan Keluarga Berencana (Dinkes-PPKB) Kota Madiun, Proses pembayaran serta evaluasi dalam proses pengangkutan limbah medis COVID-19.

Bentuk pengawasan yang dilaksanakan oleh Dinas Kesehatan Pengendalian Penduduk dan Keluarga Berencana (Dinkes-PPKB) Kota Madiun dalam kerjasama pengelolaan limbah medis COVID-19 ini adalah:

Prakerjasama, dengan melaksanakan survei kepada PT. Triata Mulia Indonesia, melaksanakan penelitian mengenai persyaratan-persyaratan kerjasama, lisensi yang dimiliki oleh PT. Triata Mulia Indonesia seperti izin operasi atau SK Menter Lingkungan Hidup RI dan Direktort Jenderal 
Perhubungan Darat yang dikeluarkan oleh serta kualifikasi perusahaan yang bekerjasama dengan PT. Triata Mulia Indonesia.

Proses kerjasama, Dinkes-PPKB Kota Madiun melaksanakan pengawasan terhadap kinerja dari PT. Triata Mulia Indonesia dalam pengambilan dan pengangkutan limbah medis COVID-19 yang meliputi ketepatan waktu pengambilan, dan ketepatan limbah sampai di tempat pengelolaan limbah. Selain melakukan pengawasan, dilakukan pula evaluasi kinerja PT Triata Mulia Indonesia dalam kerjasama pengelolaan limbah medis COVID-19 ini.

\section{Intensif}

Intensif merupakan kewajiban yang harus diberikan oleh pemerintah dalam hal ini Dinas Kesehatan Pengendalian Penduduk dan Keluarga Berencana (Dinkes-PPKB) KotaMadiun kepada pihak swasta yang telah melaksanakan tanggung jawabnya sebagai bentuk balas jasa agar proyek kerjasama dalam pengelolaan limbah medis COVID-19 dapat berjalan dengan efektif. Insentif sendiri ditujukan untuk memberikan kepastian keuntungan kepada pihak swasta yang melakukan kemitraan dalam kerjasama pengelolaan limbah medis COVID-19 ini. Intensif yang diberikan pihak kepada PT. Triata Mulia Indonesia yaitu berupa pembiayaan atas jasa pengangkutan limbah medis COVID-19. Adapun besaran harga dalam pengelolaan limbah ini sebesar Rp. 18.000 (delapan belas ribu rupiah) per kilogram, yang dibayarkan setelah Dinkes-PPKB menerima manifes yang dikirimkan oleh PT. Triata Mulia Indonesia.

\section{Kesimpulan}

Kerjasama dalam hal pengelolaan limbah medis COVID-19 antara Dinas Kesehatan Pengendalian Penduduk dan Keluarga Berencana (Dinkes-PPKB) Kota Madiun dengan PT. Triata Mulia Indonesia sebagai telah dilaksanakan selama 5 (lima) bulan terhitung sejak tanggal 2 Nopember 2020. Pemilihan PT. Triata Mulia Indonesia didasari karena perusahaan ini telah memiliki izi n operasi serta track record yang baik dalam pengelolaan limbah medis B3.

Peran dari Dinkes-PPKB Kota Madiun dalam kerjasama ini adalah sebagai pihak penghasil limbah medis dari tempat isolasi pasien COVID-19 di Gedung Asrama Haji dan Kota Madiun dan Emergency Medical Train (EMT) milik PT. INKA (Persero), sebagai pihak yang melakukan pengemasan limbah medis sesuai dengan prosedur yang berlaku, serta menjalankan fungsi pengawasan dalam kerjasama pengelolaan limbah medis COVID-19. PT. Sedangkan PT Triata Mulia Indonesia berperan sebagai transporter atau pengangkut limbah medis COVID-19 serta menentukan perusahaan mana yang akan melakukan pengolahan limbah medis.

Sistem pembayaran pengelolaan limbah medis COVID-19 dilakukan setelah Dinkes-PPKB Kota Madiun menerima Manifes limbah Bahan Berbahaya dan Beracun yang dikirimkan oleh PT. Triata Mulia Indonesia sebagai bukti bahwa limbah medis telah sampai kepada pihak perusahaan pengolah.

Kerjasama antara Dinas Kesehatan Pengendalian Penduduk dan Keluarga Berencana (DinkesPPKB) Kota Madiun dengan PT. Triata Mulia Utama dalam hal pengelolaan limbah medis COVID-19 sudah berjalan dengan efektif dikarenakan kedua belah pihak sudah menjalankan perannya masingmasing dengan baik.

\section{Reference}

Amrullah, A. A. (2019). Analisis Pengelolaan Limbah Medis Puskesmas di Kecamatan Babulu Kabupaten Penajam Paser Utara Berdasarkan Permenkes Nomor 27 Tahun 2017. Husada Mahakam: Jurnal Kesehatan, 4(8), 453. https://doi.org/10.35963/hmjk.v4i8.154

dashboard.madiunkota.go.id. (2021). Monitoring Data COVID-19 Kota Madiun.

Hikmah, D. A., Maulana, A., \& Kriswibowo, A. (2020). Public Private People Partnership as Tourism 
Development Strategy for Kepulauan Bawean. JURNAL GOVERNANSI, 6(1), 27-35.

Kriswibowo, A., Pramestya, E. A., \& Prasetyo, K. (2020). Implementasi Public Private Partnership dalam Pembangunan Wisata di Kabupaten Sumenep. Jurnal Ilmiah Ilmu A dministrasi Publik: Jurnal Pemikiran Dan Penelitian Administrasi Publik, 10(1), 213-224.

Liputan6.com. (2021). Vaksinasi COVID-19 Berpotensi Timbulkan 7,5 Juta Kg Limbah Medis. Liputan6.Com.

Mardiyansyah, K. (2021). Pemerintah Kembali Terbitkan SE soal Limbah Medis Covid-19, Ini Penjelasannya. Okezone.Com.

Miles, M. B., Huberman, A. M., \& Saldana, J. (2014). Qualitative Data Analysis: A Methods Sourcebook (3rd ed.). SAGE Publication, Inc.

Milward, H. B., \& Provan, K. G. (2000). Governing the Hollow State. Journal of Public Administration Research and Theory, 10(2), 359-379. https://doi.org/10.1093/oxfordjournals.jpart.a024273

Munawir, M., Madani, M., \& Fatmawati, F. (2019). Implementasi Kebijakan Penanggulangan Kemiskinan (Studi Kasus Program Kube-Fm Dinas Sosial Dan Ketenagakerjaan Kabupaten Bantaeng). JPPM: Journal of Public ..., 1(2).

Prasetiawan, T. (2020). Permasalahan Limbah Medis COVID-19 di Indonesia. Info Singkat (Kajian Singkat Terhadap Isu Aktual Dan Strategis), XII(9), 13-18.

Republika.co.id. (2021). Limbah Medis Covid-19 Menumpuk, Ini Tanggapan Kemenkes. Republika.Co.Id.

Sugiyono. (2019). Metode Penelitian Kuantitatif, Kualitatif, dan R\&D (2nd ed.). CV Alfabeta.

Sulfiani, andi ni'mah. (2020). Kerjasama Pemerintah dan Swasta Dalam Pengelolaan Parkir di RSUD Sawerigading Kota Palopo. Jurnal I La Galigo |Jurnal A dministrasi Publik, 3(1), 48-56.

Undang-Undang RI. (2009). Undang-Undang No. 32 Tahun 2009 tentang Perlindungan dan Pengelolaan Lingkungan Hidup. 